\title{
Size at sexual maturity of male Lucensosergia lucens (Decapoda: Sergestidae) in Suruga Bay, Japan
}

\author{
Wataru Doi, Hirofumi Washiyama, Nobuhiro Suzuki
}

\begin{abstract}
This study investigated size at sexual maturity of the male sergestid shrimp Lucensosergia lucens ("Sakura-ebi” in Japanese). The shrimps were captured in the inner part of Suruga Bay, Japan in August 2013 using experimental trawls. Carapace length (CL), body length (BL), development of petasma, and presence of spermatophores in the terminal ampoule were documented. Probabilities of maturity as a function of CL were modeled using general linear models with a binomial and logit link function and predicted the CL at which $50 \%$ of individuals were mature $\left(C L_{50}\right)$. Morphologically mature males had a petasma connected with the pars astringens, and the basal part of the pars media was developed. In physiologically mature males, chambers in terminal ampoules were filled with spermatophores, including spermatozoa and appendages. $C L_{50}(\mathrm{~mm})$ was estimated to be $8.87(=27.86 \mathrm{~mm} \mathrm{BL})$ and 7.84 ( $=24.65 \mathrm{~mm} \mathrm{BL}$ ) based on the morphological and physiological criteria, respectively. It is believed that most of the age- 0 males attain sexual maturity within the first year and mature males are exploited in the autumn fishing season (October-December).
\end{abstract}

Key words: petasma, spermatophore, terminal ampoule

\section{Introduction}

Lucensosergia lucens (known as "Sakura-ebi" in Japanese), a small pelagic shrimp belonging to the family Sergestidae, is distributed only in the western Pacific area from Tokyo Bay, Japan, to Tung-kang, southwestern Taiwan, and presumably off the coasts of Borneo, the Philippines, and New Guinea (Omori \& Hashimoto, 2020). This species is an important target of commercial fisheries in Suruga Bay (Omori, 1969), Tung-kang, and around Gueishan Island, Taiwan (Omori et al., 1988; Imai et al., 2013). In Suruga Bay, L. lucens has been caught by pelagic trawl fishing since 1894 (Omori, 1995), but the annual catch has gradually decreased with some fluctuations (Kobayashi, 2002). Catch data analysis suggested that these catch fluctuations reflect the annual changes in the abundance and biomass of shrimp (Fukui et al., 2004; Sakuma et al., 2010). During the 2010s, the annual catch remained at ca. 1,000 tons, but abruptly decreased to the historic low of 300 tons in 2018 and has been $<100$ tons since 2019 (Shizuoka Fisheries Research Institution, 2021). The fishery for this shrimp in Suruga Bay is currently managed under stricter self-regulation by fishermen (Shizuoka Prefecture, 2021).

Overfishing not only diminishes stock size but also causes changes in life history characteristics. Numerical models have suggested that size variation at the onset of sexual maturity can be caused by fishing pressure (Charnov, 1981; Ernande et al., 2004). In fact, size at maturity (SAM) for females is used as an index to assess the impact of fishing on the stock (Shin et al., 2005). Although SAM concurrently declines with spawning stock size in some commercially exploited decapods (Lipcius \& 
Stockhausen, 2002; Kodama et al., 2004), environmental factors (mainly temperature) are thought to be the main cause of SAM variation (Chiba et al., 2000; Little \& Watson, 2005; Koeller et al., 2007). It has been suggested that the SAM of recent cohorts of female L. lucens has become smaller than that of the 1960s and the 1990s (Omori, 1969; Suzuki et al., 2012) as stated by Tanaka \& Saitou (2008), Washiyama et al. (2017), and Doi et al. (2018a). However, factors causing smaller SAM in female $L$. $l u$ cens remain unknown, and male SAM has yet to be studied.

Several studies have described the reproductive biology of $L$. lucens other than female SAM: spawning season begins in late May and lasts until the middle of November, with the greatest spawn occurring in July and August (Omori, 1969; Suzuki et al., 2012; Doi et al., 2018a). Spawning occurs in the upper layers at night, where one female can release approximately 1,700-2,300 eggs (Omori, 1969; Kaneko \& Omori, 2012). Compared to females, aspects of male reproductive biology are poorly understood. First, morphological sexual dimorphisms and secondary sexual characteristics of males have been described (Omori, 1969). Second, mating seems to occur in spring and early summer, because females inseminated with sperm plugs could be observed in May and June (Suzuki et al., 2012). During copulation, male penaeoids emit right and left spermatophores from their terminal ampoules (ejaculatory ducts; Bell \& Lightner, 1988; Chow et al., 1991; Fransozo et al., 2016; Feng et al., 2018), after which they are transferred and deposited into the thelycum (female modified posterior thoracic sternites) by using the petasma (male modified endopods of the first pleopods) (Bauer, 1991). The presence of spermatophores in the terminal ampoule and a complete petasma indicate physiological and morphological sexual maturity of males. A better understanding of the basic male reproductive biology is critical for improving our under- standing of the biology of the commercially important $L$. lucens. The aim of the present study was to first reveal the SAM of male $L$. lucens in Suruga Bay using morphological (petasma) and physiological (spermatophores in terminal ampoule) traits and their availability as determinants of maturity.

\section{Materials and Methods}

\section{Sampling}

The shrimps were collected around their spawning ground (offshore the Fujikawa River) in the inner part of Suruga Bay (Fig. 1) on August 26th, 2013, during their main spawning season (Omori, 1969; Suzuki et al., 2012; Doi et al., 2018b). Sampling was conducted onboard the Research Vessel Suruga-Maru of the Shizuoka Prefecture Fisheries Research Institute using a MOHT net. The net was $8.30 \mathrm{~m}$ long, with a mouth opening of $1.43 \mathrm{~m} \times 1.43 \mathrm{~m}$ and a mesh size of $3.18 \mathrm{~mm}$. The net was towed from 19:54 to 20:11 at a speed of 2.0 kt at 50$58 \mathrm{~m}$ depth. The shrimps spawn their eggs mainly in the upper layers at night (Omori, 1969). Individuals of L. lucens were sorted for each haul, immersed in $10 \%$ seawater formalin on-board, and transported to the laboratory.

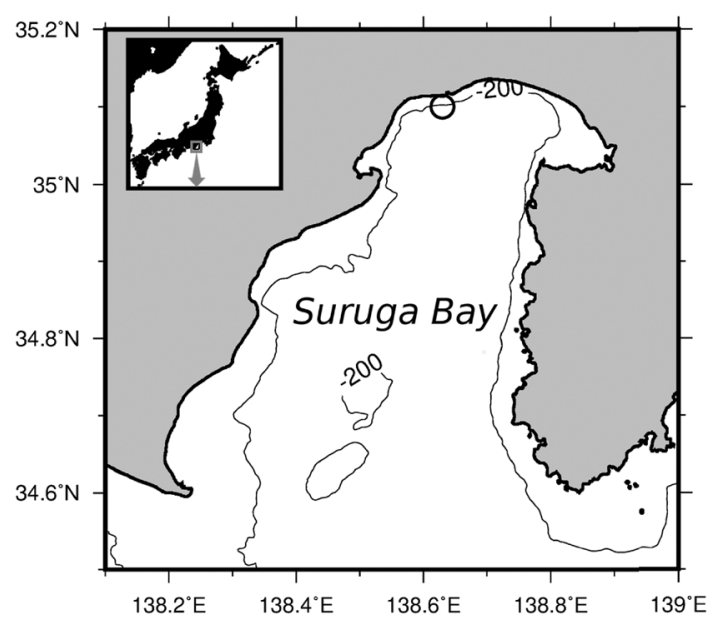

Fig. 1. Map showing a sampling site (circle) in Suruga Bay, Japan. 


\section{Measurements}

After the species of each specimen was confirmed by Hayashi (1992), sex was determined by the presence or absence of petasma. The carapace length (CL) (from the base of the rostrum to the posterior edge of the carapace) and body length (BL) (from the base of the rostrum to the posterior end of the telson) were measured to the nearest $0.01 \mathrm{~mm}$. Measurements of small structures were performed with the aid of a stereomicroscope fitted with an ocular micrometer and camera lucida. BL was used to compare with the results of previous studies. $\mathrm{BL}$ in the previous studies was converted to $\mathrm{CL}$ based on Omori et al. (1973).

The life span of L. lucens is about 15 months (Omori, 1969). During the spawning season, the population of L. lucens consists of cohorts hatched in recent years (Doi et al., 2018b). For morphological maturity analysis, 96 males with a CL between $4.41-8.56 \mathrm{~mm}$, and 15 males with a CL between 10.25-12.32 mm were selected as a group of males hatched in the current year (2013 year class) and previous year (2012 year class) (Omori, 1969). The petasma (symmetrically paired and jointed copulatory endopods on the first pleopod), which transfers spermatophores from gonopores to the female thelycum (Omori, 1969), stained with methylene blue, was examined under a binocular microscope to quantify the degree of ontogenetic development.

For physiological maturity analysis, 56 males with a CL between 4.41-8.56 $\mathrm{mm}$ and 11 males with a CL between 10.25-12.32 mm were selected from the 2013 and 2012 year classes, respectively (Omori, 1969). To confirm the presence of spermatophores within the terminal ampoules, a series of horizontal sections were made for the males. After excision of the abdomen and appendages, the cephalothorax was immersed in Davidson's solution for 1 week for demineralization. Thereafter, it was dehydrated in ethanol, embedded in paraffin wax, sectioned at a thickness of 5-6 $\mu \mathrm{m}$ from the ventral side, stained with Mayer's hematoxylin and $1 \%$ eosin and then observed under a light microscope.

\section{Statistical analysis}

To estimate the probability of maturity (ProMat) as a function of CL at the population level, a logistic model was used for the morphological maturity (completed petasma on the first pleopods) or physiological maturity (presence of spermatophores in the terminal ampoule): ProMat $=1 /\{1+\exp [-(\alpha+\beta \cdot C L)]\}$ (e.g., Mollet et al., 2000). The model was fitted using a general linear model (GLM) with a binomial and logit link function by the stats package in $\mathrm{R}$ version 4.0.2 ( $\mathrm{R}$ Core Team, 2020). Overdispersion in the data was assessed by comparing the ratio of Pearson's chi-square statistics to the residual degrees of freedom, deeming a value considerably larger than 1.0 to represent evidence of overdispersion (Hosmer et al., 2013). Overdispersion was also assessed using a chi-squared test fitting a model, using a quasibinomial model (Kabacoff, 2011). Two parameters $(\alpha, \beta)$ of the logistic models were used to predict the CL at which $50 \%$ of individuals were mature $\left(C L_{50}=-\alpha / \beta\right)$ (Mollet et al., 2000).

\section{$\square$ Results}

\section{Petasma}

The five developmental stages of petasma are divided based on distinctive morphological features (Fig. 2A-E): Stage I (Fig. 2A), undivided rod-like structure; Stage II (Fig. 2B) is divided into three parts: pars astringens (pa), pars externa (pe), and pars media (pm), with the processus ventralis (pv) and lobus connectens (lc) elongating shortly at the distal part of the pm; Stage III (Fig. 2C), pa becomes less round and sharper, pe and pm are more elongated (tip of pv extends further than that of lc); Stage IV (Fig. 2D), lobus terminalis (lt) are clearly divided from lc and all structures are 

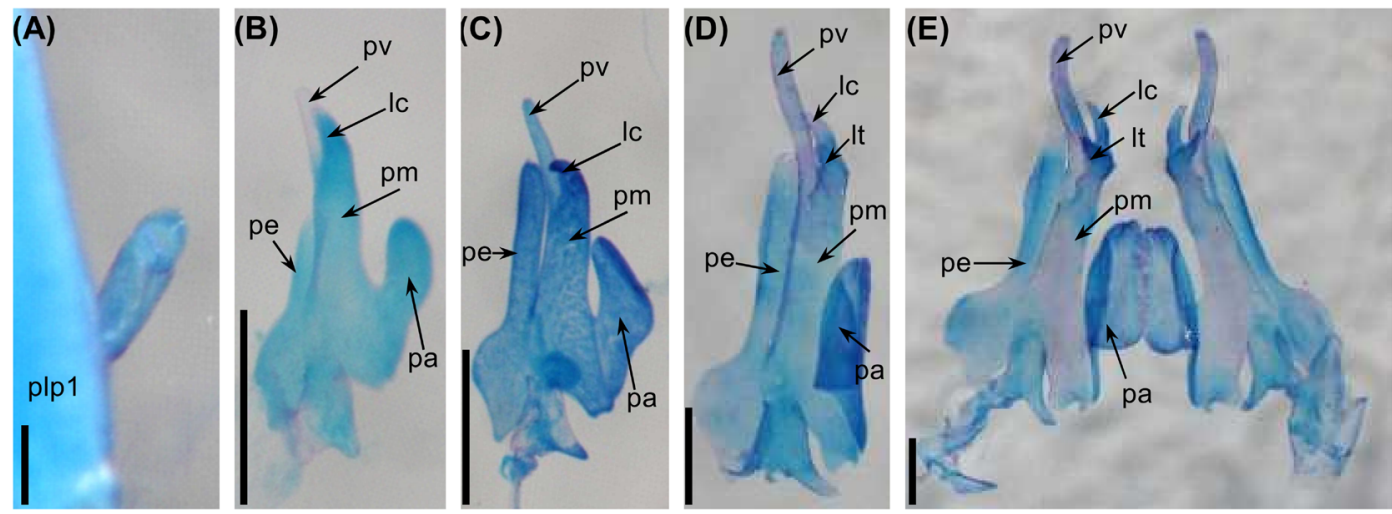

Fig. 2. Photographs of five developmental stages (I-V) of the petasma of male Lucensosergia lucens. Ventral-view of the right petasma at stage I-IV (A-D) and the jointed right and left petasmas at stage V (E). plp1, first pleopod; pa, pars astringens; pe, pars externa; lc, lobus connectens; 1t, lobus terminalis; pm, pars media; pv, processus ventralis; Scale bars $=0.1 \mathrm{~mm}(\mathrm{~A})$ and $0.5 \mathrm{~mm}(\mathrm{~B}-\mathrm{E})$.

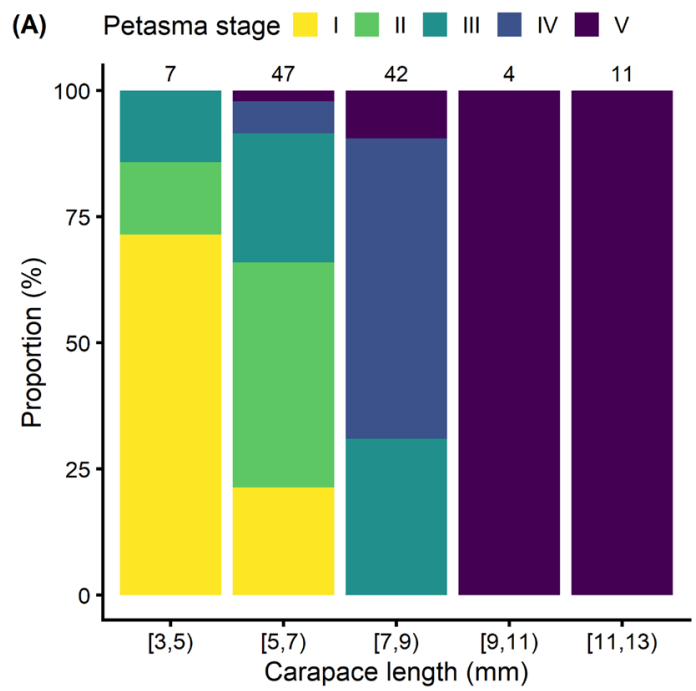

(B)

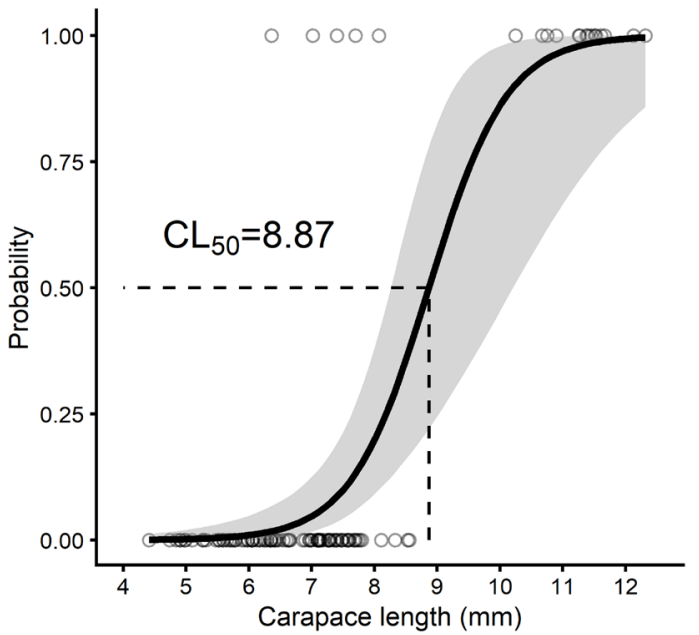

Fig. 3. Relationship between carapace length (CL) and development of the petasma of male Lucensosergia lucens. (A) Proportion of five developmental stages (see Fig. 2) of the $2 \mathrm{~mm}$ CL class. Brackets and parentheses mean that end of the range is inclusive and exclusive, respectively. (B) Probability of morphological maturity $(0=$ immature; $1=$ mature, having stage V petasma) against CL. The curve and shaded area are logistic equations for the proportion of maturity against CL and its $95 \%$ confidence intervals, respectively.

more elongated, but the right and left petasmas are not jointed; Stage V (Fig. 2E), the right and left petasmas are jointed with pa.

The proportion of males with a more developed petasma increased with larger CL ranges (Fig. 3A). Males with stage $\mathrm{V}$ petasmas had CL ranges between $6.36-12.32 \mathrm{~mm}(n=20)$. A portion of males with CL ranges 5-9 $\mathrm{mm}$ and all males with $C L$ ranges $\geq 9 \mathrm{~mm}$ had complete petasmas, showing that a part of age-0 (2013 year class) and all the age-1 males (2012 year class) attained morphological maturity. All males with stage $\mathrm{V}$ petasmas had spermatophores in their terminal ampoule, except for five males which did not receive a histological examination.

The logistic function of the ProMat for morphological maturity was estimated by the GLM as fol- 
lows (Fig. 3B): ProMat $=1 /\{1+\exp [-(-14.293$ $+1.612 \cdot C L)]\}$, and $C L_{50}(\mathrm{~mm})$ based on the morphological maturity was estimated to be 8.87 (= $27.86 \mathrm{~mm} \mathrm{BL})$ with the 8.26-10.21 range (= 26.38-31.22 mm BL) having a 95\% confidence interval. The ratio of Pearson's chi-square statistics to the residual degrees of freedom suggested that there was no overdispersion in the data $(103.65 / 109.00=0.95)$. A chi-square test for overdispersion comparing the binomial and quasibinomial models resulted in $p=0.63$, suggesting a lack of evidence for overdispersion.

\section{Terminal ampoule}

The terminal ampoule was surrounded by a muscular layer and consists of chambers lined by epithelial cells (Fig. 4). Typhlosoles, secretory epithelium of duct structures did not reach from vas deferens. There was no content within the chambers of the immature males (Fig. 4A). In mature males, the primary and appendage chambers contained spermatophores, including sperm mass and glutinous material (plugs and adhesives connecting the right and left spermatophores, respectively) (Fig. 4B).

Histological observations showed no spermatophores inside the terminal ampoule, nor the terminal ampoule itself, in a series of longitudinal sections for 45 males with CL ranges be- tween 4.74-8.56 mm, although the presence of spermatophores inside the terminal ampoule was confirmed in 22 males with CL ranges between 7.02-12.32 mm (Fig. 5A). A part of age-0 and all age- 1 males attained physiological maturity. Among these physiological mature males, 7 males with CL ranges of $7.10-8.53 \mathrm{~mm}$ possessed stage IV petasmas.

The GLM for the proportion of physiological maturity was as follows (Fig. 5B): ProMat $=1$ / $\{1+\exp [-(-18.041+2.302 \cdot C L)]\}$, and $C L_{50}$ $(\mathrm{mm})$ based on the physiological maturity was estimated to be $7.84(=24.65 \mathrm{~mm} \mathrm{BL})$ with the 7.50-8.82 range (23.92-26.07 $\mathrm{mm} \mathrm{BL}$ ) having a $95 \%$ confidence interval. There was no evidence of overdispersion $(39.30 / 65.00=0.60$; chisquare test for overdispersion, $p=1.00$ ).

\section{Discussion}

The present study successfully described the ontogenetic development of the petasma. In Sergestidae, an enlarged and elongated petasma and epi- or mesopelagic taxa is associated with the colonization of the water column where the water turbulence and currents cause mating interference (Lunina \& Vereshchaka, 2017). Moreover, the species have an intricately sculptured "open thelycum", a spermatophore with a
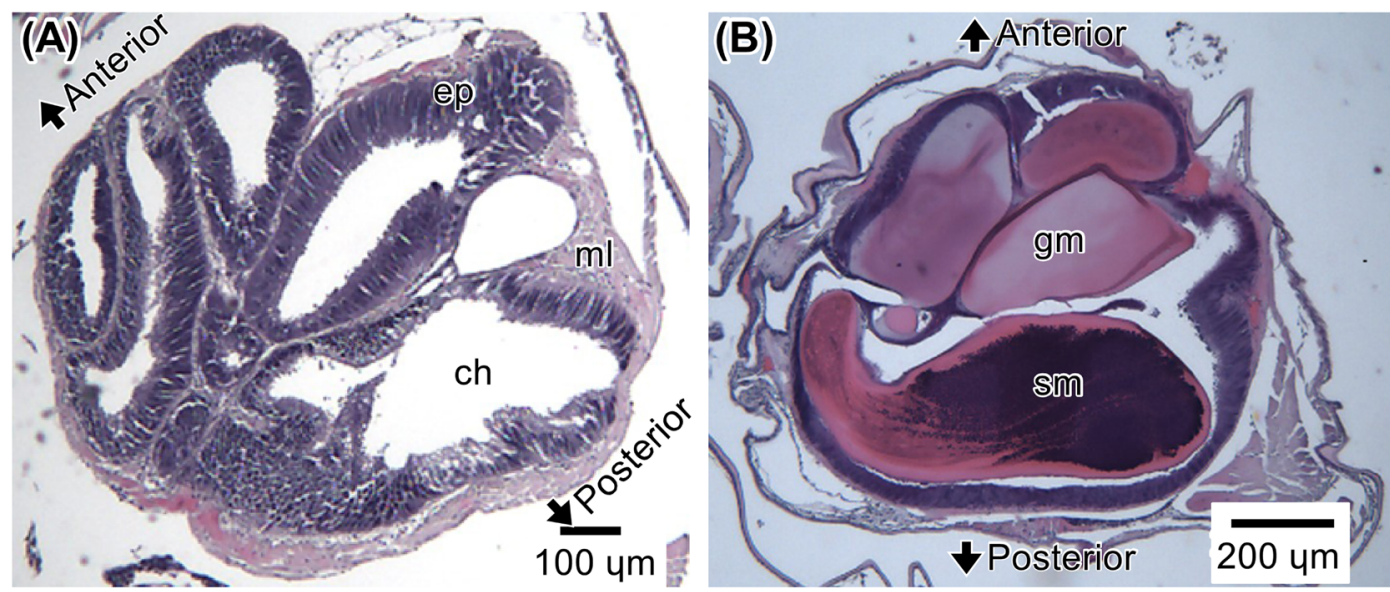

Fig. 4. Light micrographs of horizontal sections of a left terminal ampoule both without (A) and with a spermatophore (B) in Lucensosergia lucens. ch, chamber; ep, epithelium; gm, glutinous material; ml, muscular layer; sm, sperm mass. 
(A)

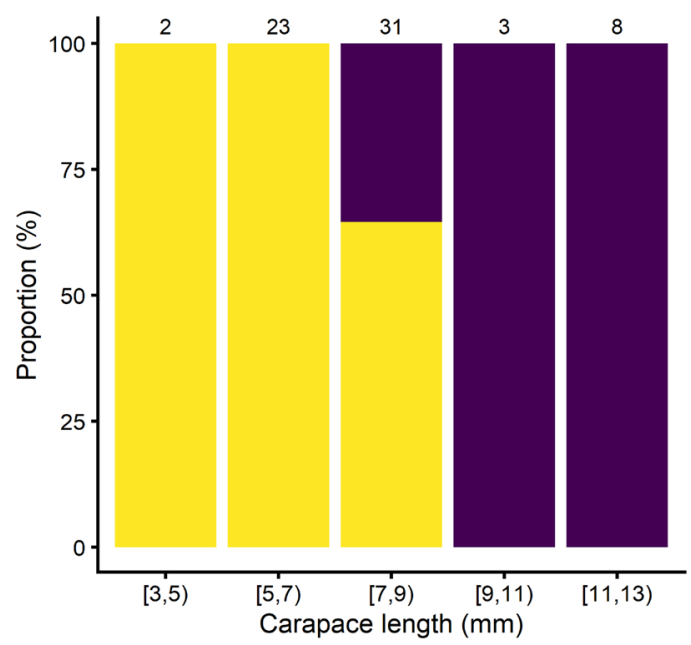

(B)

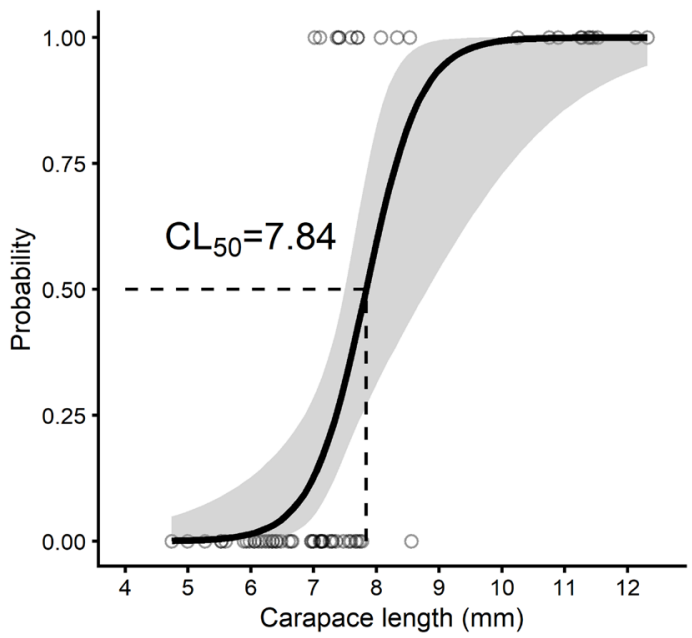

Fig. 5. Relationship between carapace length $(\mathrm{CL})$ and absence $(\mathrm{A})$ /presence $(\mathrm{P})$ of spermatophores in terminal ampoule of male Lucensosergia lucens. (A) Proportion of males with/without spermatophores in terminal ampoules of $2 \mathrm{~mm}$ CL class. Brackets and parentheses mean that end of the range is inclusive and exclusive, respectively. (B) Probability of physiological maturity $(0=$ immature; 1 = mature, having spermatophores in terminal ampoule) against CL. The curve and shaded area are logistic equations for the proportion of maturity against CL and its $95 \%$ confidence intervals, respectively.

complex appearance (Bauer, 2013). The thelycum of female L. lucens is of this open type (Hayashi, 1992), and the spermatophores have specialized accessory structures such as wings, flanges and plates (sperm plug) to assist with attachment to a female (Doi et al., personal observation). The complex development process in the petasma of L. lucens provides an easier index for assessment of morphological maturity.

Morphological features of the terminal ampoule of L. lucens (Fig. 4) are similar to those of Eusergestes similis, the only species for which histological observations of the terminal ampoule have been performed in Sergestidae (Genthe, 1969; as Sergestes similis). The terminal ampoule of Sergestidae, including the present species, contains elliptic or pear-shaped chambers and do not have typhlosoles or incomplete tissue folds, which keep their contents isolated in ducts, as seen in some penaeids (e.g., King, 1948; Bell \& Lightner, 1988; Chow et al., 1991; Fransozo et al., 2016). The male reproductive system including testis and vas deferens of $L$. lucens needs to be analyzed microscopically to understand the mechanism underlying spermatophore formation.

Both morphological and histological observations confirmed that the 2012 year class ( $>$ $12 \mathrm{~mm} \mathrm{CL}$ ) and a portion of the 2013 year class (6-10 mm CL) were sexually mature in males as well as females (Doi et al., 2018a). The morphological SAM was larger than the physiological SAM, and some physiological mature males did not have stage $\mathrm{V}$ petasmas. From these facts, it is thought that the stage $\mathrm{V}$ petasma is a good indicator of mature males, although physiological maturity may precede morphological maturity. The estimated $B L_{50}$ in males $(24.65-27.86 \mathrm{~mm} \mathrm{BL})$ is smaller than that of females (30-34 mm BL; Doi et al., 2018a) (=8-9 mm CL). Smaller modes in the length frequency distribution of the catch in October 1964 and 1965 were $28-30 \mathrm{~mm}$ or 30 $32 \mathrm{~mm}$ BL bins $(=7.7-8.3$ or $8.3-8.8 \mathrm{~mm}$ CL), respectively (Omori, 1969). Sakuma et al. (2010) analyzed the catch data between 1998 and 2008 and indicated that the mean BL of 
age- 0 males in November and December was 28.9-32.9 $\mathrm{mm}$ and $29.1-33.9 \mathrm{~mm}$ BL respectively ( $=8.0-9.1$ and $8.0-9.3 \mathrm{~mm} \mathrm{CL}$ ). It is inferred that some age- 0 males attain sexual maturity before October, and the age- 0 mature males are exploited in the autumn fishing season (October-December). Laboratory rearing experiments showed that the effects of temperature on molt frequency and size increment in L. lucens (Omori, 1971; Fukui et al., 2003). A statistical model showed that sea surface temperature in the bay between August and September could explain average BL in the annual autumn fishing season and the presence of optimal temperature for growth of L. lucens (Ohnishi, 2004). Thus, the SAM should be studied in the annual fishing season to confirm the fishing pressure on immature/mature age- 0 males.

The present study demonstrates that mature males can be identified by confirming the joint between the right and left petasmas (Fig. 2E), as observed in E. similis (Genthe, 1969). For female L. lucens, ovarian color aided the classification of immature and mature shrimps (Doi et al., 2017). Using these simple methods to discriminate mature shrimps, their occurrence can easily be monitored. These results will contribute to a better understanding of the mechanism and variation in the temporal variation of SAM of L. lucens and their stock management in Suruga Bay, Japan.

\section{Acknowledgments}

We thank T. Nakaike, J. Nakai, S. Sugiyama, S. Ogihara, and A. Nakahiro (all from Tokai University) for their help in histological observation and the captain and crew of R. V. Suruga-Maru for their assistance to sampling. We also would like to thank Editage (www.editage. com) for English language editing. This study was partly supported by Grants-in-Aid for Scientific Research from the Ministry of Education, Culture, Sports, Science and Technology of Japan (26850118) and the Research and
Study Program of Tokai University Educational System General Research Organization to W. D.

\section{$\square$ Literature Cited}

Bauer, R. T., 1991. Sperm transfer and storage structures in penaeoid shrimps: A functional and phylogenetic perspective. In R. T. Bauer \& J. W. Martin, (eds.), Crustacean Sexual Biology, Columbia University Press, New York, pp. 183-207.

Bauer, R. T., 2013. Adaptive modification of appendages for grooming (cleaning, antifouling) and reproduction in the Crustacea. In: L. Watling, \& M. Thiel, (eds.), Functional Morphology and Diversity, Oxford University Press, New York, pp. 337-375.

Bell, T. A., \& Lightner, D. V., 1988. A Handbook of Normal Penaeid Shrimp Histology. 114 pp. World Aquaculture Society, Baton Rouge, Louisiana.

Charnov, E. L., 1981. Sex reversal in Pandalus borealis: effect of a shrimp fishery? Marine Biology Letters, 2: 53-57.

Chiba, S., Goshima, S., \& Mizushima, T., 2000. Factors affecting the occurrence of early maturing males in the protandrous pandalid shrimp Pandalus latirostris. Marine Ecology Progress Series, 203: 215-224.

Chow, S., Dougherty, M. M., Dougherty, W. J., \& Sandifer, P. A., 1991. Spermatophore formation in the white shrimps Penaeus setiferus and $P$. vannamei. Journal of Crustacean Biology, 11: 201-216.

Doi, W., Nakahiro, A., Washiyama, H., \& Suzuki, N., 2018a. Size at sexual maturity and spawning fraction of female sergestid shrimp (Lucensosergia lucens) in Suruga Bay, Japan. Aquaculture Science, 66: 103109. (in Japanese with English abstract)

Doi, W., Nakahiro, A., Washiyama, H., \& Suzuki, N., 2018b. Spawning rate estimation and histological characteristics of post-spawning ovaries of the sergestid shrimp Lucensosergia lucens based on shipboard spawning experiments. Aquaculture Science, 66: 11-16. 
(in Japanese with English abstract)

Doi, W., Washiyama, H., Furuichi, K., Osumi, M., \& Suzuki, N., 2017. Maturity stage determination of female sergestid shrimp Lucensosergia lucens based on ovary color. Nippon Suisan Gakkaishi, 83: 183-190. (in Japanese with English abstract)

Ernande, B., Dieckmann, U., \& Heino, M., 2004. Adaptive changes in harvested populations: Plasticity and evolution of age and size at maturation. Proceedings of the Royal Society B: Biological Sciences, 271: 415-423.

Feng, T., Paterson, B., \& Johnston, S., 2018. A morphological study of the male reproductive tract, post-testicular acrosome maturation and spermatophore formation in the black tiger prawn (Penaeus monodon). Journal of Morphology, 279: 1290-1300.

Fransozo, V., Fernandes, A. B., López-Greco, L. S., Zara, F. J., \& Santos, D. C., 2016. Functional morphology of the male reproductive system of the white shrimp Litopenaeus schmitti (Burkenroad, 1936) (Crustacea, Penaeidea) compared to other Litopenaeus. Invertebrate Reproduction and Development, 60: 161-174.

Fukui, A., Hara, T., Ito, D., Hosho, T., \& Uotani, I., 2004. Abundance estimation of sergestid shrimp Sergia lucens in Suruga Bay. Nippon Suisan Gakkaishi, 70: 592-597. (in Japanese with English abstract)

Fukui, A., Tuchiya, T., Kanbe, Y., Kita, K., \& Uotani, I., 2003. Molting of sergestid shrimp under laboratory conditions. Nippon Suisan Gakkaishi, 69: 376-379. (in Japanese with English abstract)

Genthe, H. C. Jr., 1969. The reproductive biology of Sergestes similis (Decapoda, Natantia). Marine Biology, 2: 203-217.

Hayashi, K.-I., 1992. Dendrobranchiata Crustaceans from Japanese Waters. 300 pp. Seibutsu Kenkyusha, Tokyo. (in Japanese)

Hosmer, Jr., D. W., Lemeshow, S., \& Sturdivant, R. X., 2013. Applied Logistic Regression. 500 pp. John Wiley \& Sons, Hoboken, New Jersey.
Imai, H., Hanamura, Y., \& Cheng, J., 2013. Genetic and morphological differentiation in the Sakura shrimp (Sergia lucens) between Japanese and Taiwanese populations. Contributions to Zoology, 82: 123-130.

Kabacoff, R., 2011. R in Action: Data Analysis and Graphics with R. 608 pp. Manning Publications, Shelter Island, New York.

Kaneko, T., \& Omori, M., 2012. The reproductive biology of Sergia lucens (Hansen) in Suruga Bay, Japan (2): Variations of carapace length, number and diameter of eggs. Bulletin of Plankton Society of Japan, 59: 82-87. (in Japanese with English abstract)

King, J. E., 1948. A study of the reproductive organs of the common marine shrimp, Penaeus setiferus (Linnaeus). Biological Bulletin, 94: 244-262.

Kobayashi, K., 2002. Sergia fishery in Suruga Bay and annual variation of its catch. Bulletin of Plankton Society of Japan, 49: 108114. (in Japanese with English abstract)

Kodama, K., Shimizu, T., Yamakawa, T., \& Aoki, I., 2004. Reproductive biology of the female Japanese mantis shrimp. Fisheries Science, 70: 734-745.

Koeller, P. A., Fuentes-Yaco, C., \& Platt, T., 2007. Decreasing shrimp (Pandalus borealis) sizes off Newfoundland and LabradorEnvironment or fishing? Fisheries Oceanography, 16: 105-115.

Lipcius, R. N., \& Stockhausen, W. T., 2002. Concurrent decline of the spawning stock, recruitment, larval abundance, and size of the blue crab Callinectes sapidus in Chesapeake Bay. Marine Ecology Progress Series, 226: 45-61.

Little, S. A., \& Watson, W. H., 2005. Differences in the size at maturity of female American lobsters, Homarus americanus, captured throughout the range of the offshore fishery. Journal of Crustacean Biology, 25: 585-592.

Lunina, A., \& Vereshchaka, A., 2017. The role of the male copulatory organs in the colonization of the pelagic by shrimp-like eucarids. Deep-Sea Research Part II: Topical Studies 
in Oceanography, 137: 327-334.

Mollet, H. F., Cliff, G., Pratt, H. L., \& Stevens, J. D., 2000. Reproductive biology of the female shortfin mako, Isurus oxyrinchus Rafinesque, 1810, with comments on the embryonic development of lamnoids. Fishery Bulletin, 98: 299-318.

Ohnishi, S., 2004. Research on the effect of the temperature for the growth of sergestid shrimp. Journal of the School of Marine Science and Technology, Tokai University, 1: 9-14. (in Japanese with English abstract)

Omori, M., 1969. The biology of a sergestid shrimp Sergestes lucens Hansen. Bulletin of the Ocean Research Institute University of Tokyo, 4: 1-83.

Omori, M., 1971. Preliminary rearing experiments on the larvae of Sergestes lucens. Marine Biology, 9: 228-234.

Omori, M., 1995. Chapter I. Introduction. In: M. Omori \& K. Shida, (eds.), "Sakura-ebi"History of One Hundred Years of the Sergestid Shrimp Fishing Industry, Shizuoka Shinbunsha, Shizuoka, pp. 21-53. (in Japanese)

Omori, M., \& Hashimoto, J., 2020. New record of Lucensosergia lucens (Hansen, 1922) in the waters off Nagasaki, western Japan. Plankton and Benthos Research, 15: 55-57.

Omori, M., Konagaya, T., \& Noya, K., 1973. History and present status of the fishery of Sergestes lucens (Penaeidea, Decapoda, Crustacea) in Suruga Bay, Japan. ICES Journal of Marine Science, 35: 61-77.

Omori, M., Ukishima, Y., \& Muranaka, F., 1988. New record of occurrence of Sergia lucens (Hansen) (Crustacea, Sergestidae) off Tungkang, Taiwan, with special reference to phylogeny and distribution of the species. Journal of the Oceanographical Society of Japan, 44: 261-267. (in Japanese with English abstract)

R Core Team, 2020. R: A Language and Environment for Statistical Computing, R Foundation for Statistical Computing, Vienna, Austria. (URL:https://www.R-project.org/)

Sakuma, T., Fukui, A., Hosho, T., \& Uotani, I.,
2010. Abundance estimation of sergestid shrimp Sergia lucens of 1998-2007 year classes in Suruga Bay. Journal of the School of Marine Science and Technology, Tokai University, 8: 1-22. (in Japanese with English abstract)

Shin, Y. J., Rochet, M. J., Jennings, S., Field, J. G., \& Gislason, H., 2005. Using size-based indicators to evaluate the ecosystem effects of fishing. ICES Journal of Marine Science, 62: 384-396.

Shizuoka Fisheries Research Institution, 2021. Sakura-ebi (Lucensosergia lucens). (URL: https://fish-exp.pref.shizuoka.jp/02fishery/ 2-5/12_sakuraebi.pdf) (in Japanese)

Shizuoka Prefecture, 2021. Catch of Sakura-ebi (Lucensosergia lucens). (URL: http://www. pref.shizuoka.jp/j-nol/m_sakuraebi.html) (in Japanese)

Suzuki, K., Nakada, C., \& Omori, M., 2012. The reproductive biology of Sergia lucens (Hansen) in Suruga Bay, Japan (1): Development of ovary, copulation and number of spawnings of individual females. Bulletin of Plankton Society of Japan, 59: 20-29. (in Japanese with English abstract)

Tanaka, T., \& Saitou, M., 2008. A small sized maturity of sergestid shrimp Sergia lucens fished in Suruga Bay. Bulletin of the Shizuoka Prefectural Fisheries Experiment Station, 43: 51-59. (in Japanese)

Washiyama, H., Nakahiro, A., Doi, W., \& Suzuki, N., 2017. Estimation of minimum body length at spawning in the sergestid shrimp (Lucensosergia lucens) in Suruga Bay. Bulletin of the Shizuoka Prefectural Fisheries Experiment Station, 50: 13-17. (in Japanese with English abstract)

\section{Addresses}

(WD) (NS) School of Marine Science and Technology, Tokai University, 3-20-1 Orido, Shimizu, Shizuoka 424-8610, Japan

(WD) Present Address: Faculty of Fisheries, Kagoshima University, 4-50-20 Shimoarata, Kagoshima 890-0056, Japan; The United 
Graduate School of Agricultural Sciences, Kagoshima University, 1-21-24 Korimoto, Kagoshima 890-0065, Kagoshima, Japan (HW) Shizuoka Prefecture Fisheries Research Institute, 136-24 Iwashigashima, Yaizu, Shizuoka 452-0032, Japan
E-mail address of corresponding author

(WD)doiw@fish.kagoshima-u.ac.jp 